\title{
IMPROVEMENT OF THE PERSONNEL CONTROL SYSTEM OF THE ENTERPRISE
}

\author{
Cherep O.G. ,Vlasova V. S. \\ Zaporizhzhia National University \\ Ukraine, 69600, Zaporizhzhia, Zhukovsky str., 66 \\ cherep2508@gmail.com,vladavlasova666@gmail.com \\ ORCID 0000-0002-3098-0105
}

Key words:

management system, personnel, qualitative structure, labor resources, staff turnover, traffic indicators, personnel structure.
The article is devoted to the issues of improving the personnel management system of the enterprise. Modern conditions of the market economy necessitate the development of fundamentally new approaches to personnel management with the awareness that the main reserve of the enterprise are employees, and outside consumers of products, the quality and competitiveness of which provides staff. The principles on which the personnel management system is based need the constant updating and refinement, as the market environment of national enterprises is constantly changing. Therefore, the principles of personnel management of the enterprise have been determined, the number and structure of personnel were considered, the qualitative composition of the store's labor resources has been studied, the indicators of employee movement have been determined, the educational and qualification level of workers has been considered. There are also a number of shortcomings in the current management system at the enterprise. The ways of improvement of the personnel management system at the enterprises in the conditions of globalization have been offered.

\section{ВДОСКОНАЛЕННЯ СИСТЕМИ КЕРУВАННЯ ПЕРСОНАЛОМ ПІДПРИСМСТВА}

\author{
Череп О.Г., Власова В.С. \\ Запорізький національний університет \\ Україна, 69600, м Запоріжжя, вул. Жуковського, 66
}

\begin{abstract}
Ключові слова:
система управління, персонал, якісна структура, трудові ресурси, плинність кадрів, показники руху, структура персоналу.
\end{abstract}

Стаття присвячена питанням вдосконалення системи управління персоналом підприємства. Сучасні умови ринкової економіки обумовлюють необхідність розробки принципово нових підходів до управління персоналом 3 усвідомленням того, що основним резервом підприємства $є$ працівники, а зовні - споживачі продукції, якість і конкурентоспроможність якої забезпечує персонал. Принципи, на яких базується система управління персоналом, потребують постійного оновлення та вдосконалення, оскільки ринкове середовище національних підприємств постійно змінюється. Тому визначено принципи управління персоналом підприємства, розглянуто чисельність та структуру персоналу, вивчено якісний склад трудових ресурсів магазину, визначено показники руху працівників, освітньо-кваліфікаційний рівень працівників. Також існує низка недоліків у поточній системі управління на підприємстві. Запропоновано шляхи вдосконалення системи управління персоналом на підприємствах в умовах глобалізації.

\section{Formulation of the problem}

The efficiency and quality of human resources management in a market economy in Ukraine are becoming increasingly important as a factor in the development and competitiveness of the enterprise. Human resource management continues to be the weakest link in the enterprise system. Managers focus on production management, finance, marketing, while improving human resource management is still underestimated. Many organizations, not only in Ukraine, but all over the world, lack highly qualified, proactive, creative employees at all levels. Personnel problems in most organizations were among the top priorities. Issues of regulation of employment and employment, development and remuneration of employees are of exceptional importance. The science of human resource management must meet the requirements of the time and develop in accordance with the everchanging socio-economic realities. Problems of personnel management at the present stage of development of economic relations remain quite relevant, so they need detailed analysis.

The situation we are witnessing in Ukraine, a change in the economic and political systems, poses both great opportunities and serious threats to every citizen. Personnel management in the situation we observe is of particular importance because it provides an opportunity to summarize and implement a range of issues of human adaptation to external conditions, to take into account personal factors in building a personnel management system of the organization. The current state of the market economy and fierce competition in world markets obliges managers to look for reliable, rational and effective models of personnel management. It is known from the world experience of personnel management that investing in new equipment at industrial enterprises does not lead to increased productivity if the "human factor" is not taken into account, that is the principles of labor organization are 
not improved and there is no systematic work on training personnel with appropriate investments.

\section{Analysis of recent research and publications}

Problems of personnel management of the enterprise and its practical implementation were comprehensively considered by such scientists as: Galaz L.V. [1], Kozak K.B. [2], Kroytor A.O. [3], Lyulchak L.O. [3], Repetatska V.V. [3], and many other domestic and foreign scientists.* Determining the areas of improvement of the current personnel management system at the enterprise is carried out taking into account current trends in the economy, which are covered in the works of domestic scientists, namely in the works of Parkhomenko N.A. [5]. Oleksenko R.I. [7], Kolot A. M. [8]. Theoretical and methodological principles of personnel management and their strategic directions are reflected in the works of economists Belyaeva S.V. [4], Vynohradska A. M. [4], Krushelnytska O.V. [5].

\section{Formulation of goals}

The objective of this work is to consider the current personnel management system on the example of the store "Eva", to identify a number of shortcomings and to suggest ways to improve the current personnel management system of the enterprise.

\section{Presentation of the main research material}

Under modern conditions, the problem of staff development is becoming increasingly important. The main task of personnel management in modern conditions is a combination of effective staff training, professional development and work motivation to develop skills of employees and encourage them to perform work at a higher level. Therefore, employees must constantly try to improve their cultural and educational level. This can be expressed in the continuous improvement of their professionalism and the development of personal cultural preferences. Personnel development is provided by measures for personnel evaluation in order to carry out production adaptation and certification of personnel, career planning of workers and professionals, stimulating staff development, etc. Regarding the educational and qualification level of the staff of the store "Eva-109" which is taken as an example, consider the data given in Table 1.

Table 1 - Educational and qualification level of employees of the store "Eva-109"

\begin{tabular}{|c|c|c|c|}
\hline Job title & $\begin{array}{l}\text { Number } \\
\text { of } \\
\text { persons }\end{array}$ & Education & $\begin{array}{l}\text { Experience in a similar } \\
\text { position }\end{array}$ \\
\hline Store manager & 1 & Higher economic, master's level & Above 5 years \\
\hline Trading hall administrator & 2 & both have incomplete higher economic & $\begin{array}{l}\text { One has } 2 \text { years } \\
\text { Another - } 3 \text { years }\end{array}$ \\
\hline Inventory inspector & 1 & Higher economic, bachelor's level & Above 2 years \\
\hline Senior storekeeper & 1 & Secondary technical & 2 years \\
\hline Sales consultant & 12 & $\begin{array}{l}2 \text { have higher level bachelor } \\
6 \text { have secondary special } \\
4 \text { have full average }\end{array}$ & $\begin{array}{l}\text { All have from } 1 \text { to } 3 \\
\text { years }\end{array}$ \\
\hline Cashier & 4 & All have a special secondary & $\begin{array}{l}\text { All have from } 1 \text { to } 2 \\
\text { years }\end{array}$ \\
\hline Storekeeper & 2 & $\begin{array}{l}\text { Three have secondary special, another has } \\
\text { higher level, bachelor }\end{array}$ & $\begin{array}{l}\text { All have from } 1 \text { to } 3 \\
\text { years }\end{array}$ \\
\hline Cleaner & 2 & Full secondary & - \\
\hline Loader & 2 & $\begin{array}{l}\text { Full secondary, secondary special } \\
\text { education }\end{array}$ & - \\
\hline
\end{tabular}

The data in Table 1 show that the qualification and educational level of the staff of the store "Eva 109" is quite high - 7 employees, which is $25.9 \%$ of their total have incomplete and complete higher education, and another 13 employees have secondary special education (48.1\%). In addition, we see that all employees of the store have experience in similar fields from 1 to 3 years, and the manager for more than 5 years. All this indicates a fairly high level of qualification of employees of the store "Eva109".
All staff of the enterprise can be divided into two groups: staff of the main activity and support staff. Table 2 shows the staff structure of the store "Eva-109".

The data in Table 2 show that in the staff structure of the studied store $85 \%$ is the staff of the main activity and $15 \%$ of support staff. We also see that the planned number of staff of the enterprise does not coincide with the actual, and the store lacks two sales consultants and one administrator of the trading floor, which is $10 \%$ of the planned number of staff. 
Table 2 - Number and structure of staff of the store "Eva-109"

\begin{tabular}{|c|c|c|c|c|}
\hline Staff categories & Job title & $\begin{array}{c}\text { Number of } \\
\text { employees } \\
\text { actual as of } \\
\text { December } 31 \text {, } \\
2019\end{array}$ & $\begin{array}{l}\text { The number of } \\
\text { employees is } \\
\text { planned } \\
\text { for } 2019 .\end{array}$ & Deviation \\
\hline Total staff & & 27 & 30 & -3 \\
\hline $\begin{array}{l}\text { 1. Personnel of the main } \\
\text { activity of all, } \\
\text { including: }\end{array}$ & & 23 & 26 & - \\
\hline \multirow{4}{*}{ - leaders } & Store manager & 1 & 1 & - \\
\hline & Trading hall administrator & 2 & 3 & -1 \\
\hline & Inventory inspector & 1 & 1 & - \\
\hline & Senior storekeeper & 1 & 1 & - \\
\hline \multirow{3}{*}{ - $\quad$ specialists } & Sales consultant & 12 & 14 & -2 \\
\hline & Cashier & 4 & 4 & - \\
\hline & Storekeeper & 2 & 2 & - \\
\hline$-\quad$ workers & - & - & - & - \\
\hline Support staff total, & & 4 & 4 & - \\
\hline \multirow{2}{*}{ - $\quad$ unskilled workers } & Cleaner & 2 & 2 & - \\
\hline & Loader & 2 & 2 & - \\
\hline
\end{tabular}

The data in Table 2 show that in the staff structure of the store in 2019 there were some changes. We see a reduction in the number of more mature employees aged 30-40 and an increase in the number of young employees aged 20 to 30 .

In addition, we see a certain trend - the store does not hire employees over 40 years, which in my opinion, can not be considered the right decision. The fact is that women (namely women predominate in the staff structure) aged 40-50 years is the most hard-working category of staff, due to the fact that they already have a well-established life and personal life, they no longer go on maternity leave, they do not small children who can often get sick, etc. Therefore, they can direct all their energy to work. In addition, women of this age, according to foreign studies, are more responsible than girls aged 20-30.

In addition, in the personnel structure of the enterprise by sex, we observe a decrease in the share of men and an increase in women, respectively. Now let's analyze the quality of the store's workforce and consider the structure of staff by age and gender (Table 3).

Table 3 - Qualitative composition of labor resources of the store "Eva-109"

\begin{tabular}{|c|c|c|c|c|}
\hline \multirow[t]{2}{*}{ Indicator } & \multicolumn{4}{|c|}{ Number of employees at the end of the year } \\
\hline & 2018 & $\begin{array}{c}\text { specific } \\
\text { weight, \% }\end{array}$ & 2019 & specific weight, $\%$ \\
\hline 1 & 2 & 3 & 4 & 5 \\
\hline Groups of employees & & & & \\
\hline By age, years: & & & & \\
\hline$-\quad$ to 20 & 3 & 10 & 2 & 7,4 \\
\hline$-\quad$ from 20 to 30 & 19 & 63,3 & 20 & 74,1 \\
\hline - $\quad$ from 30 to 40 & 8 & 26,7 & 5 & 18,5 \\
\hline - $\quad$ from 40 to 50 & - & - & - & - \\
\hline$-\quad$ older 60 & - & - & - & - \\
\hline Total & 30 & 100 & 27 & 100 \\
\hline By sex: & & & & \\
\hline$-\quad$ men & 6 & 20 & 4 & 14,8 \\
\hline - women & 24 & 80 & 23 & 85,2 \\
\hline Total & 30 & 100 & 27 & 100 \\
\hline
\end{tabular}


Next, we analyze the indicators of movement and consistency of personnel (Table 4).

Table 4 - Indicators of the movement of store employees for 2018-2019

\begin{tabular}{|c|c|c|c|c|}
\hline $\begin{array}{l}\text { № } \\
\text { s /n } \\
\end{array}$ & Indicators & 2018 & 2019 & Absolute changes (+/-) \\
\hline 1 & 2 & 3 & 4 & 5 \\
\hline 1 & $\begin{array}{c}\text { There were employees at the } \\
\text { beginning of the period }\end{array}$ & 32 & 29 & -3 \\
\hline 2 & Accepted at the enterprise & 21 & 25 & +4 \\
\hline \multirow[t]{2}{*}{3} & Left the company & 24 & 26 & +2 \\
\hline & Including : & & & \\
\hline 4 & - for training & 2 & 1 & -1 \\
\hline 5 & - - to the Armed Forces & - & - & - \\
\hline 6 & - to retire & - & - & - \\
\hline 7 & - voluntarily & 19 & 20 & +1 \\
\hline 8 & $\begin{array}{c}\text { - by reduction, etc. reasons } \\
\text { provided by law }\end{array}$ & - & - & - \\
\hline 9 & $\begin{array}{c}\text { - for violation of labor } \\
\text { discipline }\end{array}$ & 3 & 5 & +2 \\
\hline 10 & $\begin{array}{l}\text { Number of employees at the end } \\
\text { of the period, pers. }\end{array}$ & 29 & 27 & -2 \\
\hline 11 & The average number of employees & 30 & 2 & -1 \\
\hline \multirow[t]{2}{*}{12} & $\begin{array}{c}\text { Number of employees who } \\
\text { worked all year round }\end{array}$ & 12 & 10 & -2 \\
\hline & Turnover ratios: & & & \\
\hline 13 & $\begin{array}{c}\text { on reception: } \\
\text { Nhs }=\text { Number of hired staff } / \\
\text { Average number of staff } \times 100 \%\end{array}$ & $70,0 \%$ & $86,2 \%$ & $+16,2 \%$ \\
\hline 14 & $\begin{array}{c}\text { on disposal: } \\
\text { Number of retired employees / } \\
\text { Average number of employees x } \\
100 \%\end{array}$ & $80,0 \%$ & $90,0 \%$ & $+10 \%$ \\
\hline 15 & $\begin{array}{c}\text { Fluidity ratio: } \\
\text { К } \Pi=\text { The number of resigned at } \\
\text { their own request and at the } \\
\text { initiative of the administration } \\
(\mathrm{p} .7+8+9) / \text { average number }\end{array}$ & $73,3 \%$ & $86,2 \%$ & $+12,9 \%$ \\
\hline 16 & $\begin{array}{l}\text { Coefficient of constancy: } \\
\text { Number of employees who } \\
\text { worked all year / Average number } \\
\text { of employees x } 100 \%\end{array}$ & $40,0 \%$ & $34,4 \%$ & $-5,6 \%$ \\
\hline
\end{tabular}

From the data in Table 4, we see that during 2019, the store's staff movement increased significantly: both the number of hired employees and the number of those who left increased. This is confirmed by the indicators of turnover on admission and disposal, as well as indicators of staff turnover (which we calculated by two methods). At the same time, we see a decrease in the coefficient of consistency of employees, which also indicates an increase in the negative trends of high staff turnover and relatively low commitment of employees to this organization.
It should be recalled that staff turnover plays an important role in the enterprise. Permanent staff working for a long time at the company, improve their skills, create an appropriate business atmosphere in the team, actively influencing the improvement of performance. Therefore, it is necessary to take into account the growth of this indicator. At the same time, the coefficients of permanence and stability of personnel, which indirectly reflect the level of wages and employee satisfaction with working conditions, are equally important. 
At each enterprise there are problems with personnel management, and the "Eva-109" store is no exception. Considering and analyzing the indicators of staff, both qualitative and quantitative, we see negative trends that do not contribute to the positive dynamics of the store.

Let's outline the main problems of the "Eva-109" store:

1) low wages compared to the high level of workload;

2) high level of staff turnover, especially among sales consultants;

3) lack of effective mechanisms for motivating work;

4) the lack of a personalized approach in assessing the achievements of staff and a subjective approach to determining the amount of remuneration of employees.

However, the biggest problems of personnel policy of the researched enterprise are the high level of staff turnover and the lack of effective mechanisms of work motivation.

In our opinion, to improve the existing personnel policy at the enterprise, to correct its main shortcomings, the following measures can be recommended:

\section{Stop staff turnover at the enterprise}

To stop the flow of staff from the company, you need to conduct a thorough and in-depth analysis of the company in individual departments, to determine the main motives of those who resign voluntarily and develop a special program to eliminate existing shortcomings in work, and especially regarding work motivation.

2. To improve the system of material motivation of work.

When determining the bonus fund of the company, which is the main material motivation for productive work, the researched company has a subjective approach to determining the amount of remuneration and corporate rules of accrual of bonuses (the greater the team contribution - the greater the reward). This approach is extremely wrong. First, the bonus of each employee should not depend on the willingness of his management to pay it, and secondly, it should take into account the individual contribution of each employee to the common cause. Of course, the team spirit trying to develop in the company is the right approach, however, when paying it should not be taken as the main criterion.

The remuneration of staff should be more dependent on the personal contribution of each employee and may only partially depend on the effectiveness of the team. As an option, you can enter a bonus model of work incentives.

By applying the proposed tips, the company will not only attract and retain skilled workers, increase their material and social interest in work and improve the performance of the store, but also raise to a new level its image as a store that really cares about its employees.

\section{Conclusions}

It can be concluded that the ultimate goal of personnel management in market relations - the maximum convergence of expectations of the enterprise and the interests of the employee, abandonment of the policy of minimum investment in personnel and assignment of the decisive role of personnel management in personnel policy and its implementation mechanism. Also, an important factor in improving the efficiency of personnel management in the enterprise is the availability and content of personnel development policy, which should include the availability of adaptation programs, systems and training programs, training and opportunities for personal development.

\section{References}

1. Galaz L.V. Influence of labor potential on the competitive status of the enterprise / L.V. Galaz // Problems of formation and implementation of competition policy: aspects of youth entrepreneurship.- Lviv: «Manuscript Company Ltd»., 2009. p.76-84.

2. Kozak K.B. Research of personnel management problems in modern enterprises / K.B. Kozak // Theoretical and practical aspects of management. 2014. № 4. p. 52-54.

3. Repetatska V.V., Lyulchak L.O., Kroytor A.A. Modern tendencies and problems of personnel management / V.V. Repetatska, L.O. Lyulchak, A.O. Kroytor // Economics. - 2012. № 5. p.113-116.

4. Vinohradskyi M.D., Belyaeva S.V., Vynohradska A.M., Shkanova O.M. Personnel management Teaching. manual. for universities. K.:CUL. 2006. 500 p.

5. Krushelnytska O.V. Personnel management [textbook] / O.V. Krushelnytska. K .: Condor, 2003. p.291-296.

6. Parkhomenko N.A. Theoretical principles of strategic personnel management / N.A. Parkhomenko // Bulletin of the V. Dahl East Ukrainian National University. - 2019. № 3 (133).

7. Oleksenko R.I. Management of human resources of enterprises in modern business conditions / R.I. Oleksenko // AgroSvit. 2010. № 14. 41 p.

8. Kolot AM "Motivation, incentives and evaluation of staff";tutorial-K: KNEU, 1998. p.224.

9. $\quad$ "Personnel management" textbook for universities / ed. A.I. Kibanova. 4th ed., Add. and revised M; Infra M., 2010. p.695. 